\title{
Investigating the Effects of Mechanical Properties of Rocks on Specific Energy and Penetration Rate of Borehole Drilling
}

\author{
Peter Kolapo
}

Received: 27 June 2020/ Accepted: 18 September 2020/Published online: 24 September 2020

(C) The Author(s) 2020

\begin{abstract}
This paper deals with the analysis of effects of mechanical properties of rock on penetration rate and specific energy. Five specimens were collected from the four locations in Federal capital territory, Abuja. These samples were subjected to laboratory point load strength index using point load testing machine. Results of the point load tests were used to estimate the uniaxial compressive strength of the rocks. The penetration rate and specific energy were determined using empirical equations. The results from the investigation showed that the rate of penetration decreases with increase in rock strength and the specific energy increases with increase in rock strength. Based on the investigation, a number of linear relationships that described the effects of mechanical properties on penetration rate in the drilling process were obtained with strong correlation coefficients.
\end{abstract}

Keywords Penetration rate Point load test . Specific energy · Uniaxial compressive strength · Tensile strength

P. Kolapo $(\square)$

School of Mining Engineering, Faculty of Engineering and the Built Environment (FEBE), University of the Witwatersrand, Johannesburg, South Africa e-mail: kolapopeter@gmail.com; peter.kolapo@students.wits.ac.za

\section{Introduction}

Rock drilling is an expensive operation that is used in mining, petroleum, civil and in underground excavation. In mining and petroleum engineering, drilling operation is widely used to intercept the potential ore or gain access to deep natural resources. The drilling process serves as an integral task as it determines the economic success or failure in tunnelling operation, mining and deep exploration industry (Messaoud 2009). In this sense, drilling performance assessment must be taken into consideration when evaluating project feasibility and economics (Munoz et al. 2016). Knowledge of behaviour of rock helps in the planning the most efficient drilling operations in terms of cost and time schedule. Prior to the drilling tasks, the accuracy of data obtained from site investigation provides information on the rock strength, deformability, geological structures, presence of failure planes such as faults, and groundwater conditions. The more accurate the information available during site investigation, the more efficient the prediction of potential challenges during the execution of the project (Copur et al. 2012).

The mechanical properties of rocks play important role in drilling operation such as prediction of fracture zone, well stability and other engineering techniques (Xu et al. 2016). Kahraman et al. (2003) stated that the specific energy (SE), the unconfined compressive strength (UCS), the Brazilian tensile strength, the 
point load strength and the Schmidt hammer rebound test values are the significant rock properties that influence the penetration rate in drilling operations. However, the UCS is the most dominant rock property for predicting penetration rate in rotary drills (Kahraman 1999). According to Clark (1982), the UCS has a close correlation with penetration rate. The penetration rate increases as rock compressive strength decreases.

In recent years, various authors have investigated theoretically and experimentally the estimation of borehole rock mass properties using various techniques. The application of sound levels produced during the rotary drilling to predict the rock properties was done by Kumar et al. (2011). A sound level of the pneumatic drill was used by Vardhan et al. (2009) to determine the compressive strength and the abrasiveness of various rock samples in the laboratory. An alternative approach used to determine the rock mass properties is the rock index test which involves the use of Schmidt rebound hammer. The use of this technique to predict UCS of rock was well documented by Buyuksagis and Goktan (2007), Li et al. (2000) and Kahraman et al. (2003) predicted the tensile strength and point load strength affecting the penetration rate of drilling machines. Tsiambaos and Sabatakakis (2004) determined the rock mass strength and the failure strength of sedimentary formations.

\subsection{Prediction of Rate of Penetration and Specific Energy in Borehole Drilling}

The correct prediction of penetration rate and specific energy assists to improve the drilling efficiency by providing information about the formation which helps the driller in the selection of suitable drill bits. The drillability of rock mass is a terminology used to describe the number of parameters that influence the drilling rate. Drillability of rock is also referred to as the penetration rate in drilling operations. According to Hartman (1959), the rate of penetration can be determined by Eq. (1):

Rate of Penetration (ROP)

$$
=\frac{\text { Total Depth Drilled }(\mathrm{m})}{\text { Total Time Taken }(\mathrm{min})}
$$

Rock drillability cannot be determined by a single index as it is influenced by various parameters (Yarali and Soyer 2013). These parameters include strength properties (UCS, tensile strength and point load strength), geological parameters, mechanical properties (brittleness of the rock, young modulus and destruction work), geological parameters, hardness and energy properties. The UCS of the rock is believed to be the most widely used parameter to predict the performance of rock drills in drilling operations. However, other rock parameters such as the tensile strength, p-wave rate and porosity can also be used to determine rock drillability (Kahraman 1999). Yasar et al. (2011) describes specific energy as another concept of assessing rock drillability. The specific energy (SE) can be defined as the minimum energy required to excavate a unit volume of rock during the drilling process. The amount of energy required widely depends on the nature and the characteristic of the rock (Davarpanah et al. 2016). The SE can also be used as the means of evaluating drilling efficiency in the drilling operation. SE indicates when there is a change in lithology which helps the driller in the selection of correct type of bit according to the drilling operation. According to Yasar et al. (2011), specific energy can be measured by using the Eq. (2).

Specific Energy $(\mathrm{SE})=\left[\left(\frac{1}{1000}\right)\left(\frac{2 \pi N T}{\left(\frac{\pi}{4}\right) d^{2}(R O P)}\right)\right]$

where SE is the calculated specific energy, $\mathrm{N}$ is the rotation speed, $\mathrm{T}$ is the torque, $\mathrm{d}$ is the borehole diameter and ROP is the rate of penetration.

\section{Description of the Geology of the Study Area}

For this study, all experiments were carried out in the Federal Capital Territory (FCT) Abuja, Nigeria. The city is located between Latitudes of $8^{0} 55^{\prime}$ and $9^{0} 08^{\prime}$ North and Longitudes of $7^{0} 21.6^{\prime}-7^{0} 32.4^{\prime}$ (Aliyu et al. 2016). The geology of FCT was previously discussed by Truswell and Cope (1963), McCurry (1976), Oyawoye (1970), Rahman (1971) and Turner (1978) to mention a few. The study area is located in the north-central part of Nigeria Precambrian Basement Complex. The basement complex formation in FCT is composed of five major rock types which are granite, mica and Feldspathic schists, gneisses, hornblende and migmatites as shown in Fig. 1 (Abam and Ngah 2013). 
Similarly, Aliyu et al. (2016) argued that the Nigeria Basement Complex comprises of four major Petrolithological rock units which are Migmatite-Gneiss complex, the Schist Belt (Metasedimentary and Metavolcanic rocks), the Older Granites (Pan African granitoid) and the Underformed Acid and Basic Dykes.

These rocks are formed as a result of four major orogenic cycles of deformation, metamorphism, and remobilization corresponding to the Liberian (2700 Ma), the Eburnean (2000 Ma), the Kibaran (1100 Ma) and the Pan-Africa cycles (600 Ma) (Aliyu et al. 2016). The topography of the study area varies from across the city. It has rugged and undulating terrain with basement rocks outcropping as hills. The lowest elevations in the area are located at the extreme southwest, while the land rises irregularly eastwards, northwards and north-westwards. The district with the highest altitude is situated in the northwest with a peak of $760 \mathrm{~m}$ above the sea level (Aliyu et al. 2016).

\section{Materials and Methods}

The study made use of an integrated approach involving the geophysical investigation of measuring the earth's resistance and the drilling system using the down-the-hole (DTH) drilling method to determine the effects of rock mass properties on the specific energy and the penetration rate. The investigations were carried out at four different sites in FCT Abuja, namely, Katampe estate, Idu-Karimu layout, SabonLugbe and federal housing authority (FHA) estate Lugbe.

\subsection{Geophysical Investigation}

The geophysical investigation is a pre-drilling operation that involves sending current into the ground through two current electrodes, while measuring and recording the earth resistance measurement resulting voltage difference between the two electrodes. In this study, the vertical electrical sounding (VES) was used to investigate the change in subsurface formation relatively with depth. In this method, a succession apparent resistivity measurement is made with increase in serrations of the active electrode (current). Eight VES are installed and the maximum electrode separation for each sounding at ML2r (AB/ $2=100 \mathrm{~m}$ ) as shown in Fig. 2.

\subsection{Estimation of UCS from the Point Load Index Test of the Rock Cuttings}

The UCS is considered as the most important mechanical property of rocks in geo-engineering and geotechnical works (Nazir et al. 2013). This parameter is widely used in stability and instability analysis of surface structures and underground openings such as in mining operation, slope stability and tunnelling (Ojo and Olaleye 2002; Saedi et al. 2018). The laboratory testing is the most reliable and indirect
Fig. 1 Image showing the Geological Map of FCT Abuja (Lekmang et al. 2016)

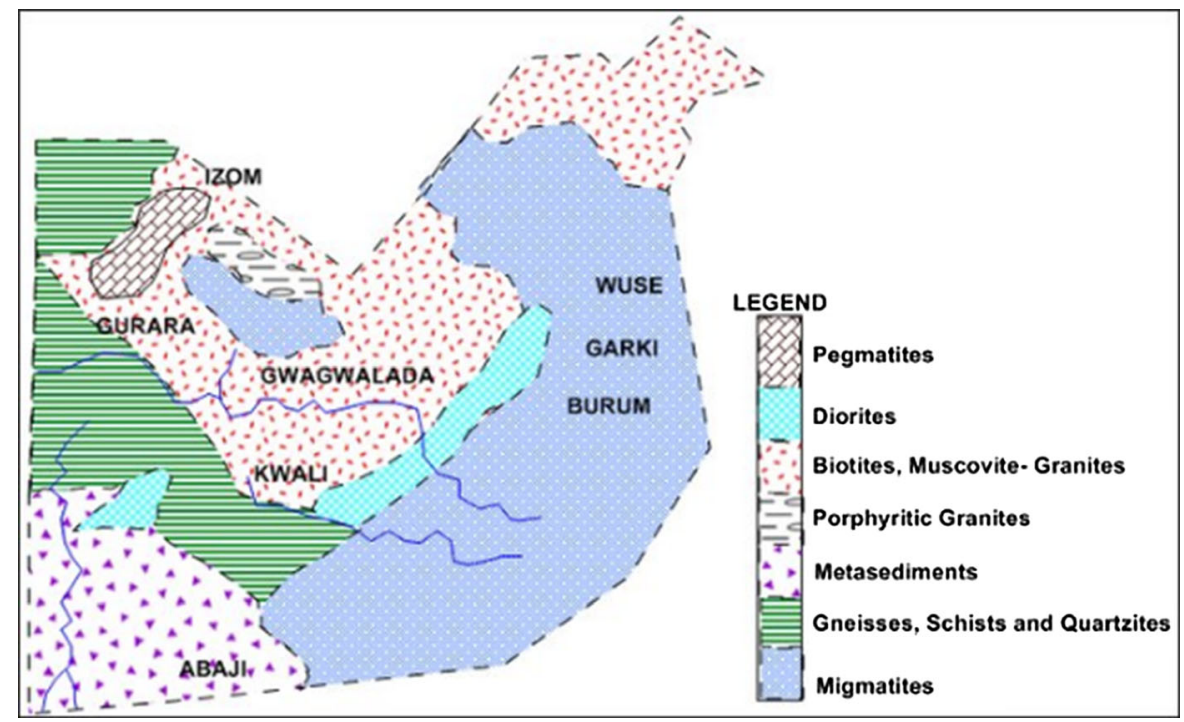



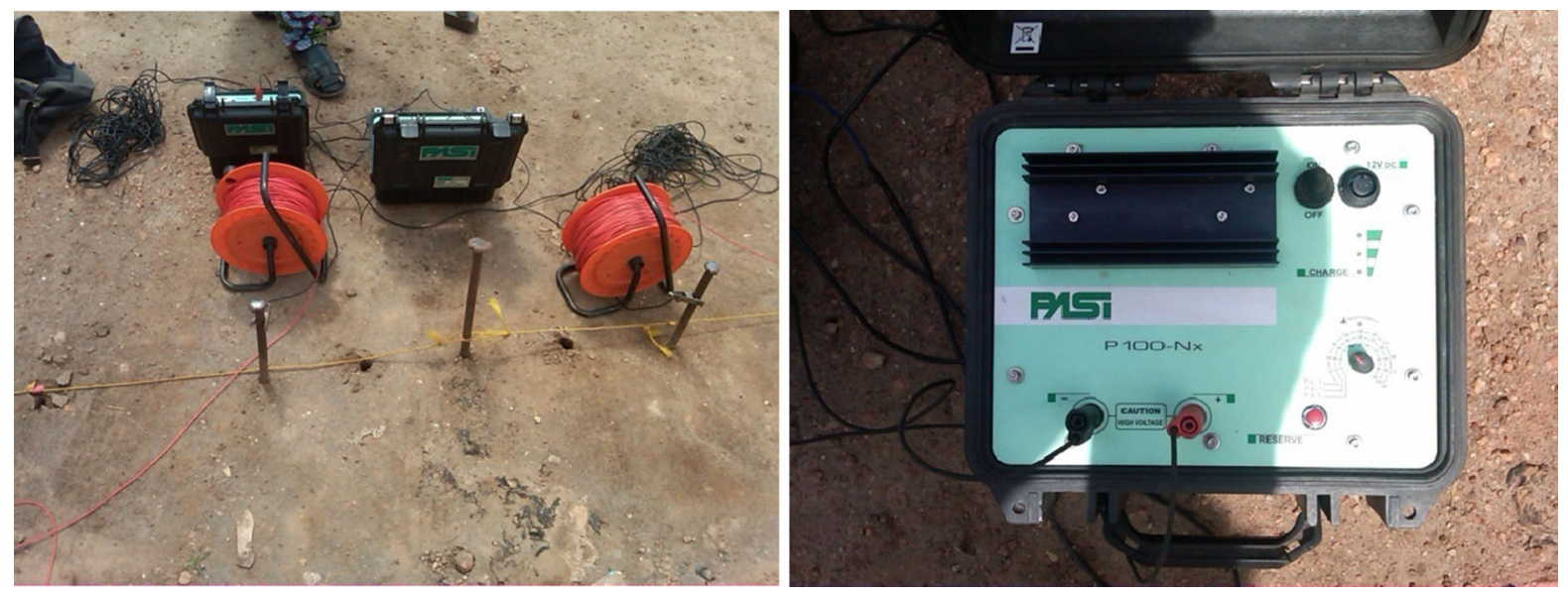

Fig. 2 Images showing Electrode used for Geophysical survey and a PASI Resistivity Meter

method of determining the UCS of rocks. Although, the laboratory testing of rocks is expensive and timeconsuming.

The point load strength tests were performed on cuboids shaped specimens with a ratio of length to width greater than 1 . The point load test is a destructive test where the rock specimens were subjected to a concentrated load applied through conical platens. A compressive machine of $1200 \mathrm{kN}$ was used. The main components of the $1200 \mathrm{kN}$ compressive machine are platens, ram, pump, gauge and release valves. The shape and size of each sample tested in a point load test can influence the results of the test as these can cause natural variations in rock quality and competence. The best possible shape for greatest accuracy is cylindrical, such as NX core. It was difficult to achieve a cylindrical core in some locations. In such cases, square or rectangular samples were used. The rock sample was placed between the two machine platens and the machine was jacked manually. This caused pressure to build up and activated the ram which compressed the sample through the platens as shown in Fig. 3.

As the load was applied, it was indicated on the gauge and the sample failure is noted and recorded. The tests were carried out based on the suggested procedures by ISRM (1985) and Brook (1985). As the applied load increased, the rock specimens would eventually fail and the corresponding failure load were recorded from the pressure gauge mounted on the point load testing machine. The stress at failure was used to calculate the load at failure by multiplying the stress value with the ram area of the point load testing machine. According to Brook (1985) and ISRM (1985), the uncorrected point load strength (Is) is calculated as follows:

$\mathrm{I}_{\mathrm{s}}=\frac{P}{D_{e}^{2}}$

where $\mathrm{P}$ is the Load at Failure $(\mathrm{kN})$ and $\mathrm{D}_{\mathrm{e}}$ is the specimen equivalent diameter.

For diametric test, $D_{e}^{2}=D^{2}$

For Axial, block and lump text $D_{e}^{2}=\frac{4 A}{\pi}$ and

$\mathrm{A}=\mathrm{WD}=$ minimum cross-sectional area that represents the specimen width and diameter.

Since the diameter of the cuttings was less than $50 \mathrm{~mm}$, the size correction was applied to obtain the correct point load strength. The formulae are as follows:

$F=\left(\frac{D_{e}}{50}\right)^{0.45}=\left(\frac{D_{e}}{2500}\right)^{0.225}$

Such that,

$\mathrm{Is}_{(50)}=\mathrm{F} \mathrm{x} \mathrm{I}_{\mathrm{s}}$

where

$f$ is the Size correction factor $=\left(\frac{D_{e}}{50}\right)^{0.45}$.

$\mathrm{F}$ is the Applied load $(\mathrm{kN})$.

De is the Equivalent core diameter $(4 \mathrm{~A} / \mathrm{p})^{0.5}(\mathrm{~m})$.

$\mathrm{A}$ is the Minimum cross-sectional area of the specimen $\left(\mathrm{mm}^{2}\right)$.

Likewise, the UCS of the specimen can also be estimated in accordance with the suggested method 

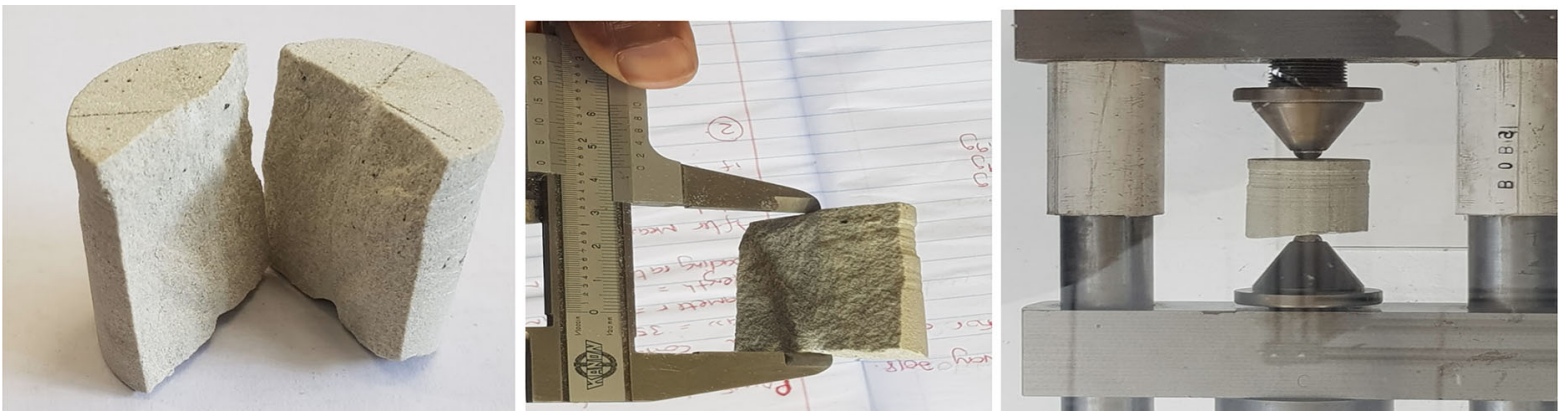

Fig. 3 Testing of samples from the borehole

from ISRM (1979) and ASTM (1985) by the equations as follows:

$\sigma=\frac{P}{A}=\frac{P}{\pi D^{2}}$

where $\mathrm{Co}=$ Uniaxial compressive strength $(\mathrm{MPa})$.

$\mathrm{P}$ is the Applied peak load $(\mathrm{kN})$, obtained from compressive machine.

$\mathrm{W}$ is the Width of the sample (m).

$\mathrm{D}$ is the Height of the sample (m).

The point load strength index $\mathrm{I}_{(50)}$ can be used to predict the UCS of the rock. The UCS is linearly correlated with the point load strength by some constant $k$ such that,

$\sigma_{(50)}=K \mathrm{I}_{\mathrm{s}(50)}$

Broch and Franklin (1972) recommended an approximate conversion of UCS with a k-value of 24, whilst ISRM (1985) suggested a range of $k$ values from 20 to 25 . However, the conversion factor may only be suitable for the prediction of UCS $\left(\sigma_{c}\right)$ in hard rocks. For soft rock, the conversion factor could be less than 24 (Agustawijaya 2007). In this study, $k$ value of 24 recommendation was taken into consideration.

$\sigma_{(50)}=24 I_{s}(50)$

However, Bieniawski (1975) suggested that the point load strength $\left.I s{ }_{(50}\right)$ is approximately 0.8 times the uniaxial tensile strength of the rock. Thus, the general relationship between the point load strength (Is) and tensile strength (Ts) is expressed in Eq. (9)

$I_{s(50)}=0.8 T_{S}$

According to Bieniawski (1975), samples E can be classified as very high strength rock, and sample D and
C are classified as high strength rock, while sample B are classified as low strength rock and A as very low strength rock.

\subsection{Estimation of Rate of Penetration and Specific Energy During Drilling}

The rate of penetration (ROP) and the SE were defined in Eq. (1) and (2) in accordance with Hartman (1959) and (Yarali and Soyer 2013). The penetration rate and the SE were used for bit performance evaluation, most especially the SE. The lower the specific energy is the higher will be the bit performance. The SE was also used to optimise the rate of penetration of bits in a limited manner and also to investigate inefficiencies in operation. The average values of penetration rate and a SE for the four borehole drilling locations in Abuja Municipal are presented in Tables 2, 3, 4, 5. At each location, a $60 \mathrm{~m}$ deep borehole was drilled and the mean values of penetration rate and SE were calculated.

\section{Evaluation of Results}

Five rock samples from each rock type were collected from each site and tested in the laboratory. The results of the tests are presented in Table 1. The correlation between the rate of penetration and the average UCS of the rock is shown in Figs. 4, 5, 6, 7. The insitu granite formations in Tables 2 and 3 (Katampe and Idu-Karimu) sites have pre-existing fractures which enhanced drilling efficiency. The drilling bit penetrated faster with a total time of $7.47 \mathrm{mins}$ and 7.84mins for Katampe and Idu-Karimu respectively. Naturally, granite is a strong rock that requires high 
Table 1 Estimation of Point load Strength (Is), Compressive Strength $\left(\mathrm{C}_{\mathrm{O}}\right)$ and Tensile Strength (Ts) of the Rock Cuttings from Four Different Boreholes

\begin{tabular}{lclll}
\hline SAMPLE & $\mathrm{I}_{\mathrm{S}}(\mathrm{MPa})$ & $\sigma(\mathrm{MPa})$ & $\mathrm{T}_{\mathrm{S}}(\mathrm{MPa})$ & Rock classification \\
\hline A & 0.8 & 19.2 & 1 & Very low strength \\
$\mathrm{B}$ & 1.45 & 34.8 & 1.81 & Low strength \\
$\mathrm{C}$ & 5.33 & 127.92 & 6.66 & High strength \\
$\mathrm{D}$ & 9.50 & 163.2 & 8.5 & High strength \\
E & 13.75 & 223 & 11.6 & Very high strength \\
Total (MPa) & 30.83 & 739.92 & 38.54 & \\
Mean Value & 6.17 & $\mathrm{I} 47.987$ & 7.71 & \\
\hline
\end{tabular}

\section{ROP vs UCS for Katampe}

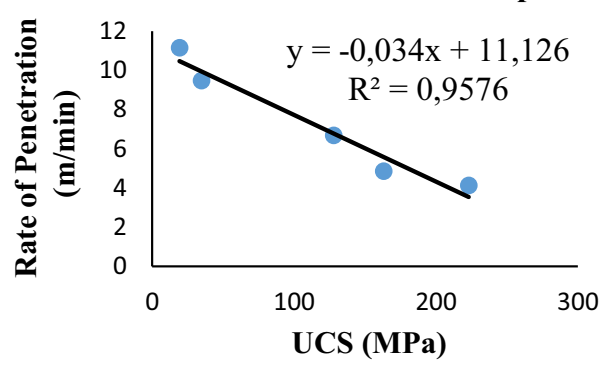

Fig. 4 Penetration rate versus UCS for Katampe

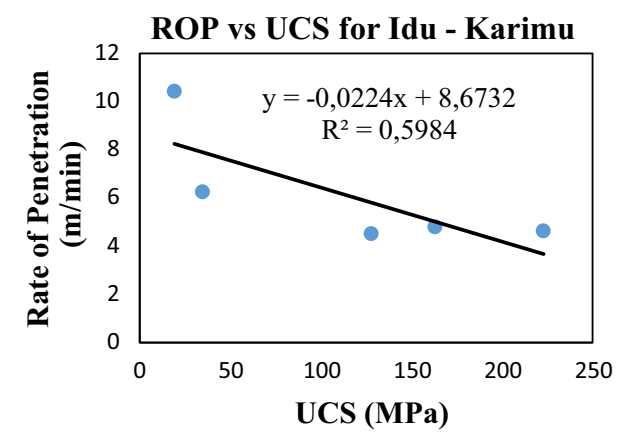

Fig. 5 Penetration rate versus UCS for Idu-Karimu

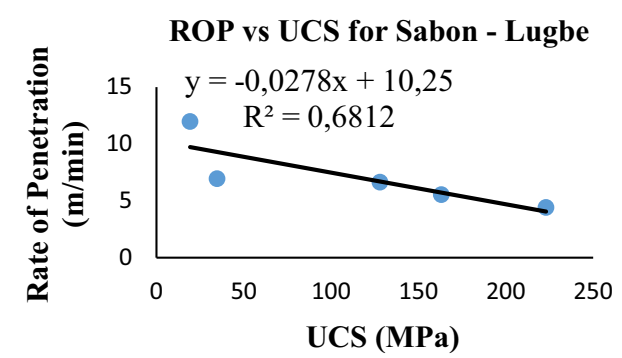

Fig. 6 Penetration rate versus UCS for Sabon-Lugbe

specific energy and reduces the penetration rate. Due to the existence of cracks and rock joints, there was a

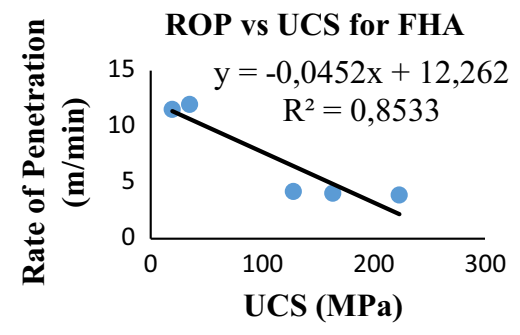

Fig. 7 Penetration rate versus UCS for FHA

reduction in the strength of the granitic formations which enhanced the drillability of the rock.

As seen from Figs. 4, 5, 6, 7, there is an inverse relation between ROP and UCS values. An increase in rock strength decreases the penetration rate of the rock bit. The linear relationship between the ROP and UCS confirms the theoretical consideration. For instance, the linear equation for Katampe is

$R O P=-0.034 \sigma+11.126, R^{2}=0.95(95 \%)$

Likewise, the rate of penetration was also compared with the tensile strength of the rock. The relationship of the penetration rate and tensile strength is presented in Figs. 8, 9, 10, 11.

Figures 8, 9, 10,11 present the correlation between the rate of penetration and tensile strength of the rock. It can be seen that the penetration rate decreases with increasing tensile strength. In addition, Figs. 8, 9, 10, 11 show a close relationship between the two parameters with the highest correlation coefficient value of $0.95(95 \%)$ and lowest of $0.59(59 \%)$ at Katampe and Sabon-Lugbe respectively. A number of useful equations can be drawn from the relationship between these two parameters. For instance, the linear equation that represents the correlation between the penetration rate and the tensile strength at FHA can be presented as: 
Table 2 Mean values of the rate of penetration rate and specific energy for Katampe

\begin{tabular}{lcclllll}
\hline Depth $(\mathrm{m})$ & Time taken $(\mathrm{min})$ & ROP $(\mathrm{m} / \mathrm{min})$ & Speed $(\mathrm{rpm})$ & Area $\left(\mathrm{m}^{2}\right)$ & Torque $(\mathrm{Nm})$ & S.E $\left(\mathrm{Nm} / \mathrm{m}^{3}\right)$ & Rock type \\
\hline $3-12$ & 0.66 & 11.15 & 320 & 48.5 & $1,375,000$ & $5,590,096,678$ & Laterite \\
$15-21$ & 1.9 & 9.48 & 320 & 48.5 & $1,375,000$ & $6,030,034,949$ & Sandy clay \\
$24-27$ & 3.83 & 6.68 & 320 & 48.5 & $1,375,000$ & $8,542,185,032$ & Sandstone \\
$30-42$ & 7.47 & 4.86 & 320 & 48.5 & $1,375,000$ & $117,620,046$ & Granite \\
$45-60$ & 12.71 & 4.12 & 320 & 48.5 & $1,375,000$ & $1,383,746,837$ & Quartzite \\
\hline
\end{tabular}

Table 3 Mean values of penetration rate and specific energy for Idu-Karimu

\begin{tabular}{llclllll}
\hline Depth $(\mathrm{m})$ & Time taken $(\mathrm{min})$ & ROP $(\mathrm{m} / \mathrm{min})$ & Speed $(\mathrm{rpm})$ & Area $\left(\mathrm{m}^{2}\right)$ & Torque $(\mathrm{Nm})$ & S.E $\left(\mathrm{Nm} / \mathrm{m}^{3}\right)$ & Rock type \\
\hline $3-9$ & 0.46 & 10.42 & 320 & 48.5 & $1,375,000$ & $5,056,952,425$ & Laterite \\
$12-15$ & 2.16 & 6.25 & 320 & 48.5 & $1,375,000$ & $9,188,028,591$ & Lateritic clay \\
$18-30$ & 5.29 & 4.52 & 320 & 48.5 & $1,375,000$ & $1,291,166,793$ & Sandstone \\
$33-42$ & 7.84 & 4.8 & 320 & 48.5 & $1,375,000$ & $1,191,055,816$ & Granite \\
$45-60$ & 11.34 & 4.63 & 320 & 48.5 & $1,375,000$ & $1,232,332,676$ & Quartzite \\
\hline
\end{tabular}

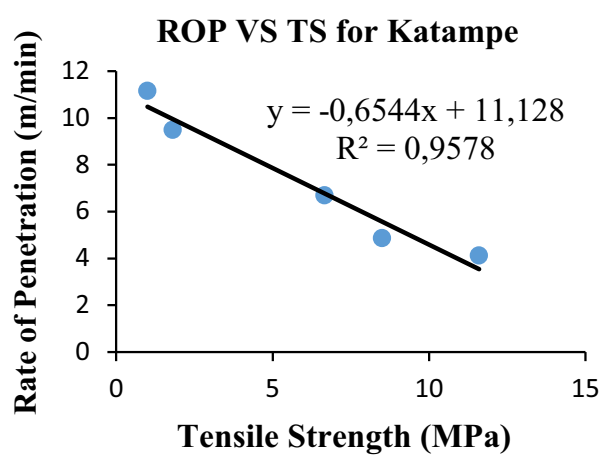

Fig. 8 Penetration rate versus TS for Katampe

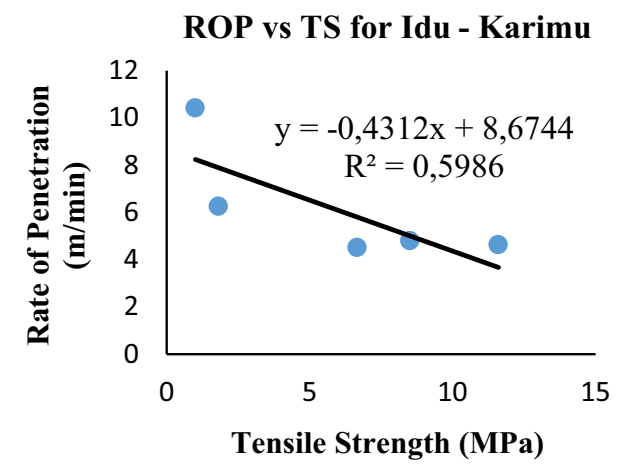

Fig. 9 Penetration rate versus TS for Idu-Karimu

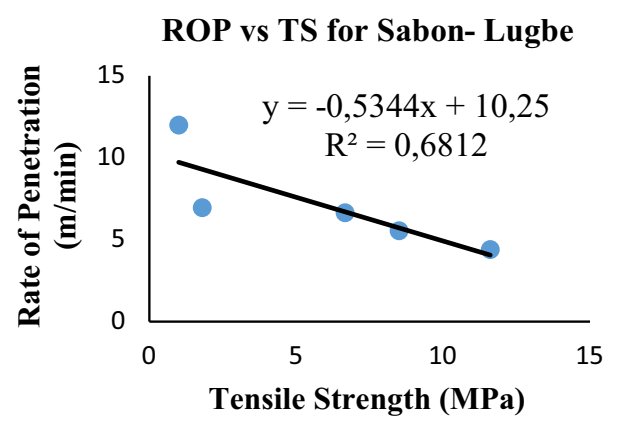

Fig. 10 Penetration rate versus TS for Sabon-Lugbe

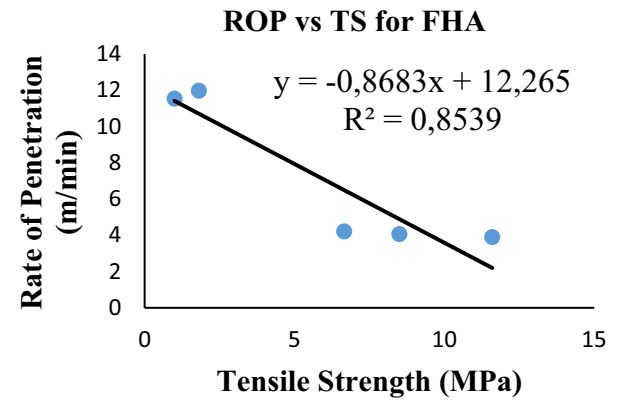

Fig. 11 Penetration rate versus TS for FHA 
$R O P=-0.8683 T_{S}+12.265 R^{2}=0.85(85 \%)$

Similarly, comparisons were made between the specific energy and the UCS for all the four sites in FCT Abuja. The correlation between specific energy and the UCS is presented in Figs. 12, 13, 14, 15.

Figures 12, 13, 14, 15 show the correlation between specific energy and UCS of rocks. This indicates that an increase in specific energy increases in the uniaxial compressive strength of the rock. The correlation equation to determine the relationship between the specific energy and the UCS for FHA is expressed in Eq. (12).

$S E=0.0167 \sigma-61.795 R^{2}=0.89(89 \%)$

Other relationships were established between the SE and the Tensile Strength of rocks as shown in Figs. 16, 17, 18, 19.

Figures 16, 17, 18, 19 show a strong correlation between the SE and the tensile strength of rocks. The graphs indicate that increase in SE causes an increase in the tensile strength of the rock. The correlation coefficient $\mathrm{R}^{2}$ ranges between $0.67(67 \%)$ and 0.96 $(96 \%)$ by a linear equations. The linear equation for Katampe is represented by

$S E=0.0012 T_{S}-53.113 R^{2}=0.96(96 \%)$

\section{Discussion of Results}

The measurements recorded from four (4) different borehole drilling operation sites in this study have shown that the properties of rock vary from one

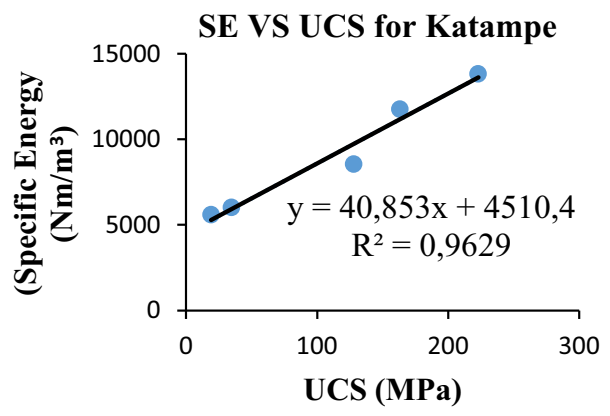

Fig. 12 Specific Energy versus UCS for Katampe

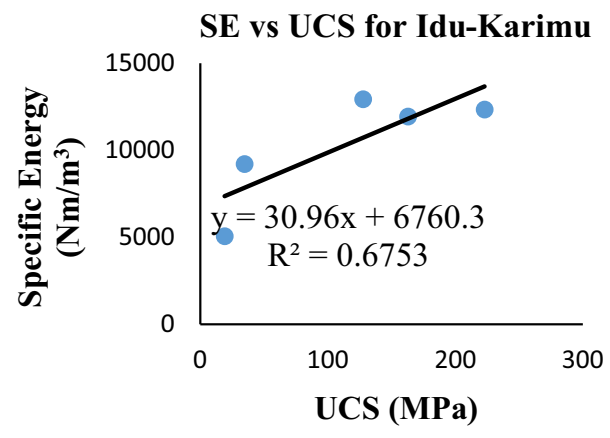

Fig. 13 Specific Energy versus UCS for Idu

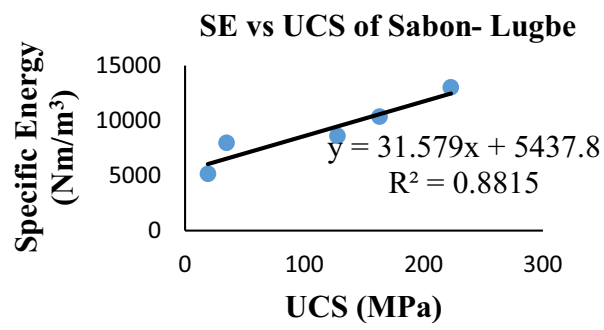

Fig. 14 Specific Energy versus UCS for Sabon

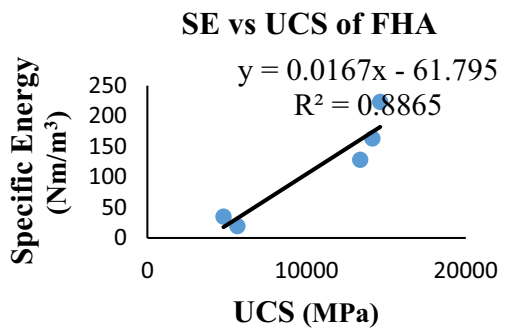

Fig. 15 Specific Energy versus UCS for FHA

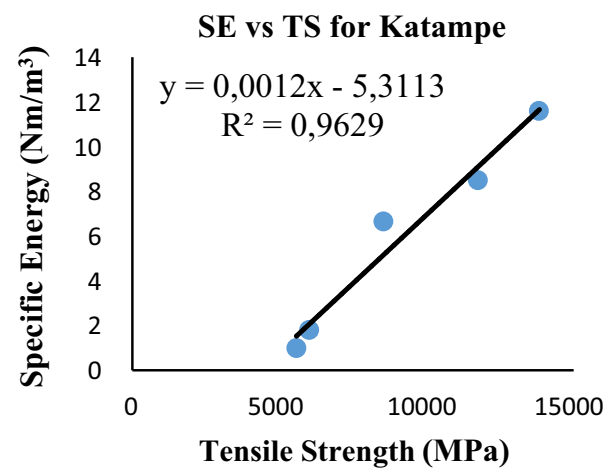

Fig. 16 SE versus TS for Katampe 


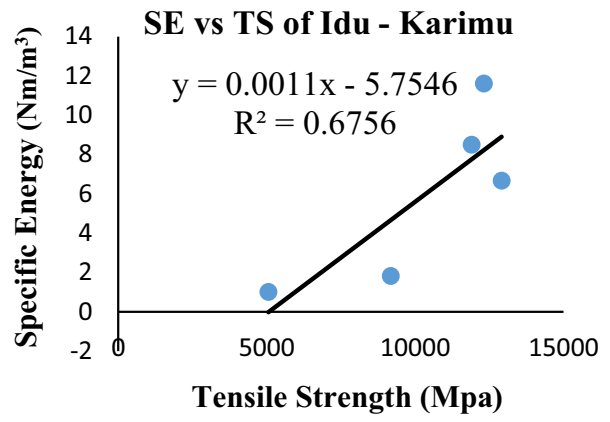

Fig. 17 SE versus TS for Idu -Karimu

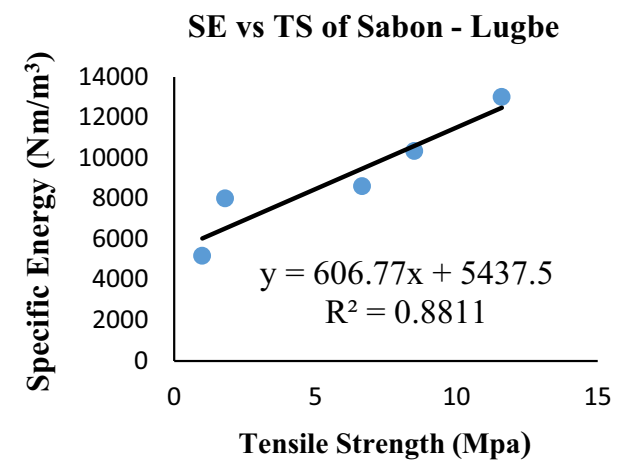

Fig. 18 SE versus TS for Sabon Lugbe

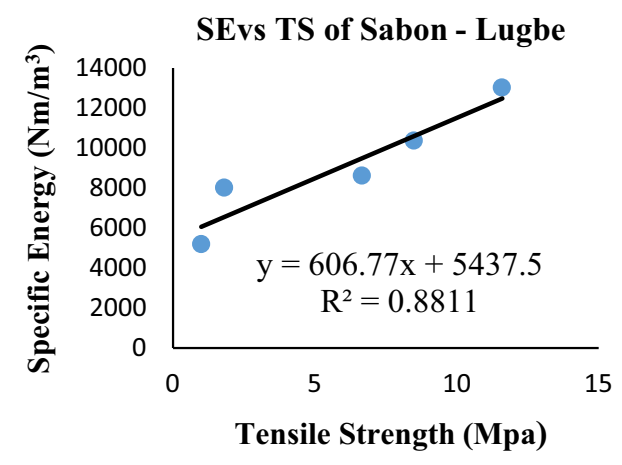

Fig. 19 SE versus TS for FHA

formation to another. The average values of the point load tests of the rock sample from the borehole samples were used to calculate the compressive and tensile strength properties of the rock. The point load index test in the laboratory indicated that sample $\mathrm{E}$ has the highest resistance to penetration with a UCS of $223 \mathrm{MPa}$ and is classified as very high strength rock. Samples D and C with compressive strength values of 163.2Mpa and 127.92 MPa respectively are classified as high strength rock material, Sample B with a compressive strength value of $34.8 \mathrm{MPa}$ is classified as low strength rock and the remaining samples A with compressive strength of 19.2 MPa is classified as very low strength rock. The rate of penetration analysis also indicates that an increase in depth causes a decrease in the penetration rate. The drill bit performed excellently in the overburden rock, while the performance was low in the basement formation.

The reduction in strength of granite formations influenced the rate of penetration and the specific energy required in the formations. Since there is a decrease in the strength of the granite rock, it is expected that the drilling bit will move faster down the hole. The reduction in strength of granite samples can be mainly attributed to the presence of microcracks or pre-existing fractures in the insitu granite rock which has significantly increased the efficiency and performance of the drilling operation. Rock properties such as uniaxial compressive strength, tensile strength, rock quality designation (RQD), plasticity, rock mass structure, and elasticity are controlled by an increase in rock joints. For instance, the insitu granite formations in Tables 2 and 3 (Katampe and Idu-Karimu) sites have inherent fractures which influenced an increase in the rate of penetration and the amount of specific energy required. Ideally, both granite and quartzite are extremely strong rocks that require high specific energy and reduce the rate of penetration. However, the existence of cracks and rock joints led to a reduction in cohesion or weak bond in the material composition of the insitu rock. The effects of the reduction in strength of granite formation caused the increase in penetration rate and reduce specific energy that enhances drilling efficiency in granite formations.

The results from this study have demonstrated how mechanical properties of rocks can offer resistance to the drilling process. The results of this study have demonstrated the strong influence of rock properties on operation parameters (penetration rate and specific energy) for the drilling process. The penetration rate shows inverse relations with the properties of rocks, that is, increase in the rock compressive strength causes reduction in the drill bit penetration rate. Similarly, the penetration rate also decreases with an increase in the tensile strength of the rock. Correlations between SE and properties of the rock show that an increase in rock compressive or tensile strengths causes an increase in the amount of energy required to remove a unit volume of rock. The results from this 
study have shown an agreement with the previous studies on the influence of rock mass properties on penetration rate and SE.

\section{Conclusion}

This study has established a number of empirical equations that described the effects of mechanical properties of rocks on penetration rate and specific required during drilling operations. The empirical relationships showed that rock strength properties have an influence on drilling operation. The increase in rock strength causes a reduction in the rate of penetration. That is, the higher the strength of the rock, the slower the rate of penetration. For Instance, Tables 2, 3, 4, 5 showed that the penetration rate was faster in the soft rocks (Laterite) compared to the high strength rocks such as granite and quartzite. The drilling of the lateritic rocks were completed around a minute while the high strength rocks took a longer period of time to drill. Contrarily to the penetration rate, the specific energy required increases with an increase in rock strength properties. The higher the strength of rocks, the higher the specific energy requires to complete the drilling operation. This study proves that the mechanical properties of the rock have an appreciable influence on the drillability of rocks. Likewise, this study highlighted importance of rock joints as a significant factor that enhances the drilling efficiency. Existence of cracks in insitu granitic rock influenced the rate of penetration and the specific energy. The drilling bit penetrated faster in fracture granite formations due to the presence of jointed rocks. Notably, there was a reduction in the amount of specific energy required for the drillability of granite formations due to presence of microcracks and pores. This study confirmed that understanding of preexisting cracks, fractures, pores and bedding planes of insitu rocks is important in evaluation of drilling performance. This helps in careful selection of drilling bits, determination drillig rate in meters per minute, and most importantly the drilling cost for a particular project.

Mechanical properties of rocks such as compressive and tensile strength are considered as the necessary site investigation input data in slope engineering analysis, quarry, mining, tunnelling, construction industry, foundation design and stability analysis of underground construction. Thus, this study has fostered more understanding of rock mass behaviour in the study area. Moreover, it will assist in the planning

Table 4 Mean values of penetration rate and specific energy for Sabon-Lugbe

\begin{tabular}{llllllll}
\hline Depth $(\mathrm{m})$ & Time taken $(\mathrm{min})$ & ROP $(\mathrm{m} / \mathrm{min})$ & Speed $(\mathrm{rpm})$ & Area $\left(\mathrm{m}^{2}\right)$ & Torque $(\mathrm{Nm})$ & S.E $\left(\mathrm{Nm} / \mathrm{m}^{3}\right)$ & Rock type \\
\hline $3-6$ & 0.37 & 11.97 & 320 & 48.5 & $1,375,000$ & $5,178,361,512$ & Laterite \\
$9-24$ & 2.33 & 6.93 & 320 & 48.5 & $1,375,000$ & $7,995,661,328$ & Mica schist \\
$27-36$ & 4.75 & 6.63 & 320 & 48.5 & $1,375,000$ & $8,598,090,798$ & Migmatitic gneiss \\
$39-48$ & 7.93 & 5.53 & 320 & 48.5 & $1,375,000$ & $1,034,852,225$ & Diorites \\
$51-60$ & 12.69 & 4.39 & 320 & 48.5 & $1,375,000$ & $1,300,909,648$ & Quartzite \\
\hline
\end{tabular}

Table 5 Mean values of penetration rate and specific energy for FHA

\begin{tabular}{llllllll}
\hline Depth $(\mathrm{m})$ & Time taken $(\mathrm{min})$ & ROP $(\mathrm{m} / \mathrm{min})$ & Speed $(\mathrm{rpm})$ & Area $\left(\mathrm{m}^{2}\right)$ & Torque $(\mathrm{Nm})$ & $\mathrm{S} . \mathrm{E}\left(\mathrm{Nm} / \mathrm{m}^{3}\right)$ & Rock type \\
\hline $3-9$ & 0.51 & 11.53 & 320 & 48.5 & $1,375,000$ & $5,658,719,206$ & Laterite \\
$12-15$ & 1.13 & 11.96 & 320 & 48.5 & $1,375,000$ & $477,454,433$ & Sandy clay \\
$18-30$ & 5.25 & 4.21 & 320 & 48.5 & $1,375,000$ & $1,337,634,047$ & Sandstone \\
$33-42$ & 9.24 & 4.05 & 320 & 48.5 & $1,375,000$ & $1,414,035,658$ & Schist quartz \\
$45-60$ & 13.44 & 3.9 & 320 & 48.5 & $1,375,000$ & $1,462,464,004$ & Quartzite \\
\hline
\end{tabular}


of excavation projects and the selection of suitable drilling methods and equipment for a particular project.

Acknowledgement The authors would like to thank and acknowledge the contribution of Mr. Onileowo Peter, the CEO of Golden Peters and Company Limited (Engineering Geological Company) and all the members of staff for their support during the study.

\section{Compliance with Ethical Standard}

Conflict of interest The authors declare that there is no known conflict of interests that could have appeared to influence the work reported in this paper.

Open Access This article is licensed under a Creative Commons Attribution 4.0 International License, which permits use, sharing, adaptation, distribution and reproduction in any medium or format, as long as you give appropriate credit to the original author(s) and the source, provide a link to the Creative Commons licence, and indicate if changes were made. The images or other third party material in this article are included in the article's Creative Commons licence, unless indicated otherwise in a credit line to the material. If material is not included in the article's Creative Commons licence and your intended use is not permitted by statutory regulation or exceeds the permitted use, you will need to obtain permission directly from the copyright holder. To view a copy of this licence, visit http://creativecommons.org/licenses/by/4.0/.

\section{References}

Abam T, Ngah S (2013) An assesment of groundwater potentials of the Central Area District and its environs, Federal Capital City, Abuja, Nigeria. Int J Eng Sci (IJES) 2(11):7-11

Agustawijaya D (2007) The uniaxial compressive strength of soft rock. Civ Eng Dimens 9(1):9-14

Aliyu M, Ojo A, Olorunfemi M (2016) Geological and Hydrogeochemical characterisation of the basement complex aquifers in the area around the Abuja city. Ife J Sci 18(2):321-330

ASTM (1985) Standard test method for determination of the point load strength of rock and application to rock strength classification. Int Soc Rock Mech Comm Test Method 22(2):51-60

Bieniawski Z (1975) The point-load test in geotechnical practice. Eng Geol 9(1):1-11

Broch E, Franklin J (1972) The point load strength test. Int J Rock Mech Min Sci 9:669-697

Brook N (1985) The equivalent core diameter method of size and shape correction in point load testing. Int J Rock Mech Min Sci Geomech 22:61-70

Buyuksagis B, Goktan R (2007) The effect of Schmidt hammer type on uniaxial compressive strength prediction of rock. Int J Rock Mech Min Sci 44:299-307
Clark G (1982) Principles of rock drilling and bit wear. Colorado School of Mines Quarterly, Denver

Copur H, Cinar M, Okten G, Bilgrin N (2012) A case study on the methane explosion in the excavtion chamber of an EPB-TBM and lessons learnt including some recent accidents. Tunn Undergr Sp Technol 27:159-167

Davarpanah A, Zarei M, Nassabeh M (2016) Assesment of mechanical specific energy aimed at im proving drilling inefficiencies and minimize instability. $\mathrm{J}$ Pet Environ Biotechnol 7(6):1-6

Hartman H (1959) Basic studies of percussion drilling. Min Eng 11(1):68-75

ISRM (1985) Suggested method for determining point load strength. Int J Rock Mech Min Sci Geomech Abst 22(2):51-60

ISRM (1979) Suggested methods for determining the uniaxial compressive strength and deformability of rock materials. Int J Rock Mech Min Sci Geomech 16(2):135-140

Kahraman S (1999) Rotary and percussive drilling prediction using regression analysis. Int $\mathrm{J}$ Rock Mech Min Sci 36:981-989

Kahraman SNB, Feridunoglu C (2003) Dominant rock properties affecting the penetration rate of percussive drills. Int $\mathbf{J}$ Rock Mech Min Sci 37:729-743

Kumar R, Vardhan H, Govindaraj M (2011) Sound level produced during rock drilling vis-a-vis rock properties. Eng Geol 123:333-337

Lekmang I et al (2016) Geotechnical investigations for infrastructural development: a case study of Daki Biyu District Federal Capital Territory, Abuja, Central Nigeria. J Geol Min Res 8(3):28-39

Li X et al (2000) Analysis of impact hammer round to estimate the rock drillability. Rock Mech Rock Eng 33:1-13

McCurry H (1976) The geology of precambian to Lower palaeozoic rocks of Northern Nigeria-a review. In: Kogbe CA (ed) Geology of Nigeria. Elizabethan Publishers, Lagos, pp 15-39

Messaoud L (2009) Influence of fluids on the essential parameters of rotary percussive drilling. Elect J Geotech Eng 14:1-8

Munoz H, Taheri A, Chanda E (2016) Rock drilling performance evaluation by an energy dissipation based rock brittleness index. Rock Mech Rock Eng 49(8):3343-3355

Nazir R, Momeni E, Armaghani D, Amin M (2013) Correlation between unconfined compressive strength and indirect tensile strength of Limestone rock samples. Elect J Geotech Eng 18:1737-1746

Ojo O, Olaleye B (2002) Strength characteristic of two Nigerian rocks. Glob J pre Appl Sci 8(4):541-549

Oyawoye M (1970) The basement complex of Nigeria. In: Dessauragie ITFJ, Whiteman AJ (eds) Ibadan African Geology. Ibadan University Press, Nigeria, pp 67-78

Rahman M (1971) Classification of rocks in the Nigerian PreCambian basemenr complex. Jos, Plateau State Nigeria, Geology of Nigeria: Annual conference of Nigerian Mining, Geological and Metallurgical Society

Saedi B, Mohammadi S, Shahbazi H (2018) Prediction of uniaxial compressive strength and elastic modulus of migmatites using various modelling techniques. Arab J Geosci 11(574):1-14 
Truswell J, Cope R (1963) The geology parts of Niger and Zaria Provinces, Northern Nigeria. Geol Surv Niger Bull 29:1-104

Tsiambaos G, Sabatakakis N (2004) Consideration on strength of intant sedimentary rocks. Eng Geol 72:261-273

Turner D (1978) The precambian and lower Paleozoic basement of Nigeria.London, Institute of Geological Science pp 255260

Vardhan H, Adhikari R, Raj M (2009) Estimation of rock properties using sound levels produced during drilling. Int $\mathrm{J}$ Rock Mech Min Sci Geomech 46(3):604-612

Xu H, Zhou W, Xie R, Da L, Xiao C, Shan Y, Zhang H (2016) Characterization of rock mechanical properties using lab tests and numerical interpretation model of well logs. Math Probl Eng. https://doi.org/10.1155/2016/5967159

Yarali O, Soyer E (2013) Assesment of relationship between drilling rate and mechanical properties of rocks. Tunn Undergr Sp Technol 33:46-53

Yasar E, Ranjith P, Viete D (2011) An experimental investigation into the drilling and physico-mechanical properties of a rock-like brittle material. J Petrol Sci Eng 76:185-193

Publisher's Note Springer Nature remains neutral with regard to jurisdictional claims in published maps and institutional affiliations. 